\section{European \\ Neurology}

\title{
Edward B. Bromfield, MD
}

\section{(1951-2009)}

Edward B. Bromfield, Chief of the Division of Epilepsy and Sleep Neurology at the Brigham and Women's Hospital, Boston, Mass., and associate professor at the Harvard School of Medicine, passed away on the night of May 10, 2009, shortly after his 58th birthday, ending a long and stoic fight against pancreatic cancer. He served on the editorial board of European Neurology since 2003 until his death.

Dr Bromfield grew up in the Boston area and graduated in psychology at Harvard in 1973. For several years, he worked as an educator for children with learning disabilities and later taught literacy skills to adults. He then entered the Harvard Medical School, where he graduated in 1983; he trained in neurology and epilepsy in Boston and at the NIH in Bethesda, MD, before starting the Epilepsy Program at the Brigham and Women's Hospital 15 years ago. Since then, he managed to progressively develop the original nucleus to a skilled team of several epileptologists and sleep neurologists, who all felt as part of a great family. They became backed by a comprehensive interdisciplinary group of neurosurgeons, neuropsychologists, psychiatrists, and social workers, as his aim has always been to offer the best possible care to patients with epilepsy. Committed to improve the quality of life of patients, he created a summer camp for children with epilepsy 10 years ago; over all these years Dr Bromfield was constantly rewarded by the great consideration and thankfulness of his numerous patients. His didactical achievements are illustrated by the 'Teacher of the year' award in 2007 from the Neurology residents program at Harvard; the prestigious J. Kiffin Penry Award for Excellence in Epilepsy Care was presented to him in the same year from the American Epilepsy Society. His scientific interests ranged from seizure semiology, to pharmacology, status epilepticus, and the interplay between epilepsy and sleep or psychiatry.

It is difficult to describe in these lines what made Dr. Bromfield outstanding; for sure, the fact that he combined

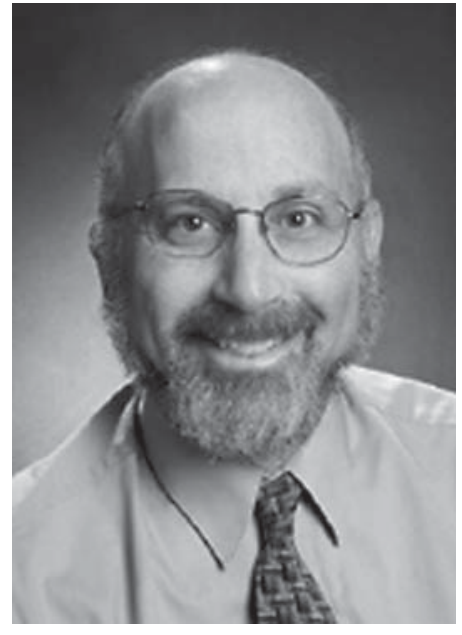

an impressive clinical and electrophysiological knowledge, accompanied by a rigorous and honest scientific approach, with a never-tiring spontaneous humanity and humor, accounts for a great part of it. He shared with his family and his numerous friends many interests, such as music (one has to remember his nightly guitar performances), basketball (he was an active player until this year) and baseball, even succeeding to 'infect' Europeans with this - at a first glance - rather static sport. To his colleagues, he appeared as a sort of a reassuring big brother, a 'gentle giant', as the president of the American Epilepsy Society recently described him. His natural, characteristic smile irradiating a natural joy of life is greatly missed.

Dr. Bromfield is survived by his father, his wife of 29 years Terry, their two adult sons Daniel and Benjamin, and his sister. The epilepsy community mourns an outstanding, dedicated, and compassionate colleague, who always acted with delicate modesty. His legacy will live on with those who had the privilege to share a segment of their professional life with him.

Dr. Andrea O. Rossetti, Lausanne

\section{KARGER}

(ㄷ) 2009 S. Karger AG, Basel

Fax +41 613061234 E-Mail karger@karger.ch www.karger.com www.karger.com/ene
Dr. Andrea O. Rossetti Service de Neurologie CHUV BH07

CH-1011 Lausanne (Switzerland)

Tel. +41 21314 1220,Fax +41 21314 1290,E-Mail andrea.rossetti@chuv.ch 